\title{
AN OVERVIEW STUDY OF WORKING CONDITION AND PRODUCTIVITY OF CONSTRUCTION LABOURS: CASE STUDY OF SUBURBAN MUMBAI REGION OF INDIA
}

\author{
Ajba Shabbir Ahmed Pawle ${ }^{1}$, Mohit Suryakant Jadhav², Mohd Ahmed Ashraf Chapra ${ }^{3}$ \\ ${ }^{I}$ Civil Engineering, Saboo Siddik College of Engineering, Maharashtra, India \\ ${ }^{2}$ Civil Engineering, Saboo Siddik College of Engineering, Maharashtra, India \\ ${ }^{3}$ Civil Engineering Saboo Siddik College of Engineering, Maharashtra, India
}

\begin{abstract}
Labour Productivity plays a significant role in the construction sector. It assists construction sector to be combative to accomplish aims and to encounter the investors and to be innovative. Productivity being a captivating theme and a prevailing subject in construction sector, guaranteed cost optimization and well-organized handling of assets. Now a day, throughout the world productivity is the major issue of concern. The objective of the research is finding the important factors influencing the fluctuations in labour productivity in construction projects of suburban Mumbai, India, evaluating the effect of the Welfare group, safety group and Output group on the fluctuations of labour productivity and suggesting recommendation to diminish the fluctuations of labour productivity. The above goals are accomplish through analysis using sets of questions based on output, welfare and safety of labour. The analysis are been shown in a tabular format in which facilities available for labours at all sites visited is calculated in percentage. Tabulated results of Reliability analysis are followed by the comments, which are based on reliability analysis and compared with the guidelines given by National Building Codes [THIRD REVISION OF SP (PART 7)] DOC: CED 46. Conclusions are been specified to improve the labour productivity at construction sites in suburban Mumbai. This paper emphasis on the ability to create change and manage labour factors affecting productivity in construction planning. Three major heads, which have vital effect on the labour productivity, are output groups, safety groups and welfare groups. Codes like National building codes and Minimum Wages Act are been considered as base for the study.
\end{abstract}

Keywords: Labour Productivity, Welfare, Safety, Output, Personal Protective Equipment (P.P.E), Comments

\section{OBJECTIVE OF STUDY}

According to the BUILDING AND OTHER CONSTRUCTION WORKER, WELFARE CESS RULE 1998, In India about more than 8.5 Million workers are engaged in Civil and building construction industries throughout the country and it is the second largest source of employment after agricultural. Therefore if the efficiency of the construction workers are improved then large amount of capital can be saved from these sectors and hence these will help in the development of the country. Now days due to detrimental conditions of labour at the site their productivity is decreasing day by day. The main reasons behind this are the huge gap between the welfare and safety requirement given by National Building Code (N.B.C) and the welfare and safety condition adopted at site. Therefore, in order to increase the productivity these gaps must be minimize and the basic necessary requirements must be made available at every site.

\section{INTRODUCTION}

\subsection{Necessity To Study Labour Productivity}

For satisfactorily completion of the construction projects, labour productivity plays a key role. In 1993, Guhathakurta and Yates, and in 2002 Jergeas and McTague states that $30 \%$ to $50 \%$ of overall project's budget consists of labour expenditure. Ten percent increment in productivity of construction workers would generates annual savings of approximately Billions to the Great Britain economy were concluded by Horner et al in the year 1989. Therefore, it is very essential to increase the labour output to achieve economy in the construction project. However, in India Labour consists one of the largest parts of the construction project cost and labour hour in performing an activity is highly vulnerable to fluctuations than other resources. Time and cost are the major aspects of construction work. Bad labour productivity causes overrun in time and cost.

Labours are the key resources of building project. Labour intensive projects are entirely depending on the productivity of the labour. For the achieving the objectives and successful completion of the goals of any construction companies labour productivity is one of the fundamental element. All civil engineering projects are entirely dependent on the productivity of the workers and equipment to achieve good results. In India, Construction projects are mainly depends upon labours with primary instrument and machinery used at the construction sites. However, the output of the labour is a dependent activity that is affected by the efficiency and output of the equipment and machinery operated by the labour. Therefore measuring the productivity of the labour is complicated and equals to measuring the efficiency of the entire system of task work 
including machines and equipment. Therefore, for the progress of the construction works, variations in labour productivity should be as low as possible.

\subsection{UNDERSTANDING LABOUR PRODUCTIVITY}

Labour productivity can be defined in the following ways: LABOUR PRODUCTIVITY is defined as the proportion of output to input attained by the construction labours at the site .The cost engineer ASSOCIATION of AMERICAN generally defines labour productivity as "Relative computation of efficiency of the labour, either desirable or undesirable, when compare to an established guideline or norms". In construction the labour output is generally, express in mass or capacity of work done and input resources is generally express in terms of wages of labour or person's working hours.

\section{CAUSES OF LOW PRODUCTIVITY}

\subsection{Labour Driving Forces And Working Condition}

\section{In India}

In majority of the developing countries like India, many workers are working with small companies. Most of the labours are appointed on contract basis or project basis or daily basis. Labours are hired on construction project bases with no assurance against period of idleness or illness, uncertainty of job and deficit of social security. On Daily basis every morning workers are gather at selected point junction of road known as "KADAINAKA" to secure work. Many times, the labours work for one week or two week in a month. Hence these all factors affect the productivity of the worker on large-scale. In addition the workers who migrate from lesser-developed countries get exploited by the labour contractor.

\subsection{LABOUR EARNINGS}

Earnings of labour are low and irregular, which result in discouragement and loss of working interest, resulting in low productivity and sometimes the labour may leave the job. In the year, 2001 Indian Labour Organisation (ILO) analysed the construction sector and conclude that in developing countries like India where the availability of labour (particularly unskilled labour) is far in surplus as compare with the availability of jobs, due to such deteriorating conditions the earning of most of construction labours are below the minimum wages. Employers try to fascinate the labours by providing them with attractive salary in returns of not allowing them to register under worker permit, which is against law. Initially it will attract the labours but then the increment in the wages of the labours will entirely be dependent upon the contractors.

\section{FACTORS AFFECTING LABOUR}

\section{PRODUCTIVITY}

ACCORDING TO NATIONAL BUILDING CODE AND SECTIONAL COMMITTEE (CED) 46. The key aspect, which tends to lower the productivity, is lack of materials, which ultimately results in delay of satisfactorily completion of project. Incomplete drawing and incompetent supervisor are the main factors. In a survey of Uganda when the time cost quality are considered, low productivity are due to

$\checkmark \quad$ Inadequate and Inexperienced supervisors

$\checkmark$ Shortage of manpower skills and abilities

$\checkmark$ Break down or shortage machinery

$\checkmark$ Lack of communication skills,

$\checkmark \quad$ Less Training period,

$\checkmark$ Inappropriate job layout,

$\checkmark$ Delay in checking of the completed work and modifying the same work

As per Alinaitwe 2007, Descending order of importance is as followed

$\checkmark \quad$ Unavailability of material

$\checkmark \quad$ Late payment of salary and wages

$\checkmark$ Suitability of plants and equipment

$\checkmark$ Supervisory incompetence

$\checkmark \quad$ Lack of manpower skills

$\checkmark$ Plant break down

$\checkmark \quad$ Late delivery of materials

$\checkmark$ Lack of labour experiences

$\checkmark$ Shortage of tools and equipment

$\checkmark$ Low remuneration

\section{LITERATURE REVIEW}

In the year 2009, Homyun Jang et al found 25 critical variables that have an impact on labour productivity and classified them into four sets, which are management of work, management technique of work, characteristic of work and component of worker.

In the year 2011, Durdyev and Mbachu recognized 56 variables, which have impact on labour productivity and characterized them into eight elements.

In the year 2007, Enshassi listed component affecting the fluctuation of productivity into 10 factors .These factors includes working labour force, governance, factors associated with work, inspiration factor with regards of time, materials resources and machinery, inadequate supervision, project related specifications, protection, quality of the worked achieved and other factors of the project.

In the year 2011, Soekiman found 113 elements that are having an impact on labour productivity and these elements are further assembles into 15 sets of elements as per their features

\section{RESEARCH METHODOLOGY}

The present work focuses on three major factors affecting labour productivity i.e. output, safety and labour welfare. The methodology used in the study is entirely based on the questionnaires prepared and actual observations on the site with respect to questionnaires. 
$\Rightarrow$ The questionnaires survey is based on major heads like output, labour welfare and labour safety. $\Rightarrow$ The reliability analysis is done by actual observation on the sites and response from the engineer in suburban Mumbai.

$\Rightarrow$ There liability analysis from different sites is calculated in tabular form through which provision of different facilities on construction sites in Mumbai suburban region is calculated in percentages.

$\rightarrow$ Tabulated results of Reliability analysis are followed by the comments which are based on reliability analysis and compared with the guidelines given by National Building Codes (N.B.C).

\section{Questionarries Survey}

(On Output, Welfare And Safety)

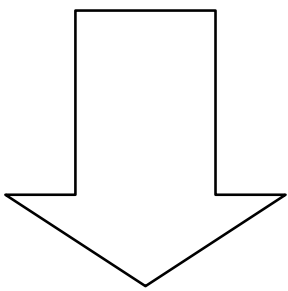

Reliability Analysis

(By Site Visit)

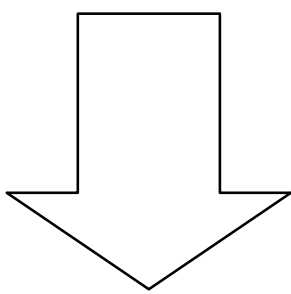

Summary

(Comparision Of All The Sites In Table Format)

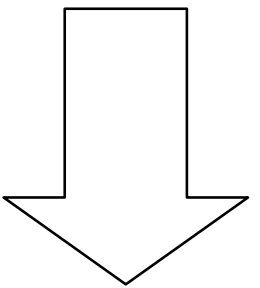

(Overview Based On Comparison Between Actual

Observations And National Building

Code (N.B.C) Guidelines)

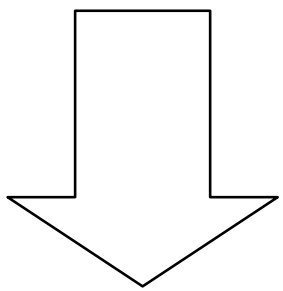

(Recommendation And Conclusion)

Fig -1: Research Methodology Used In The Study

\section{SITE DETAILS}

The sites, which are visited for the study of "LABOUR OUTPUT, LABOUR SAFETY, LABOUR WELFARE "the details are given below

Table -1: Site Details

\begin{tabular}{|c|c|c|c|}
\hline Locality & AREA & $\begin{array}{c}\text { Type of } \\
\text { Construction }\end{array}$ & $\begin{array}{c}\text { Type of } \\
\text { Building }\end{array}$ \\
\hline Airoli & 5000 sq.ft & $\begin{array}{c}\text { R.C.C Frame } \\
\text { Structure }\end{array}$ & $\begin{array}{c}\text { Community } \\
\text { Building }\end{array}$ \\
\hline Goregaon & 12000 sq.ft & $\begin{array}{c}\text { R.C.C Frame } \\
\text { Structure }\end{array}$ & $\begin{array}{c}\text { Residentail } \\
\text { Building }\end{array}$ \\
\hline $\begin{array}{c}\text { Lower } \\
\text { Parel }\end{array}$ & 75000 sq.ft & $\begin{array}{c}\text { R.C.C Frame and } \\
\text { Precaste } \\
\text { Structure }\end{array}$ & $\begin{array}{c}\text { Residential } \\
\text { Building }\end{array}$ \\
\hline Borivali & 5000 sq.ft & $\begin{array}{c}\text { R.C.C Frame } \\
\text { Structure }\end{array}$ & $\begin{array}{c}\text { College } \\
\text { Building }\end{array}$ \\
\hline Byculla & 15000 sq.ft & $\begin{array}{c}\text { R.C.C Frame } \\
\text { Structure }\end{array}$ & $\begin{array}{c}\text { Residentail } \\
\text { Building }\end{array}$ \\
\hline Dadar & 5000 sq.ft & $\begin{array}{c}\text { R.C.C Frame } \\
\text { Structure }\end{array}$ & $\begin{array}{c}\text { Residentail } \\
\text { Building }\end{array}$ \\
\hline Kurla & 7500 sq.ft & $\begin{array}{c}\text { R.C.C Frame } \\
\text { Structure }\end{array}$ & $\begin{array}{c}\text { Residentail } \\
\text { Building }\end{array}$ \\
\hline Kalina & 9000 sq.ft & $\begin{array}{c}\text { R.C.C Frame } \\
\text { Structure }\end{array}$ & $\begin{array}{c}\text { Residentail } \\
\text { Building }\end{array}$ \\
\hline
\end{tabular}

Table -2: Showing Facilities Available At Different Sites

\begin{tabular}{|c|c|c|c|c|c|c|c|c|c|}
\hline $\begin{array}{l}\text { LABOUR } \\
\text { FACILITIES }\end{array}$ & $\mathbf{i}$ & ii & iii & iv & $\mathbf{v}$ & vi & vii & viii & $\begin{array}{l}\text { Result } \\
\text { In } \\
\text { Percent }\end{array}$ \\
\hline \multicolumn{10}{|l|}{ WELFARE } \\
\hline $\begin{array}{l}\text { Whether drinking } \\
\text { facilities are sufficient } \\
\text { and wholesome at the } \\
\text { site? }\end{array}$ & 0 & 1 & 1 & 0 & 1 & 0 & 0 & 0 & 37.5 \\
\hline $\begin{array}{l}\text { Whether sufficient W.C } \\
\text { units are provided? }\end{array}$ & 1 & 1 & 1 & 1 & 1 & 1 & 1 & 1 & 100 \\
\hline $\begin{array}{l}\text { In sanitary units } \\
\text { facilities like water, } \\
\text { lighting and hygienic } \\
\text { condition etc are } \\
\text { present? }\end{array}$ & 0 & 1 & 1 & 0 & 1 & 0 & 0 & 0 & 37.5 \\
\hline $\begin{array}{l}\text { Whether canteen on no } \\
\text { profit and no loss basis } \\
\text { are available at site? }\end{array}$ & 0 & 1 & 1 & 0 & 0 & 0 & 0 & 0 & 25 \\
\hline $\begin{array}{l}\text { Whether FIRST AID } \\
\text { centre facilities are } \\
\text { present at site? }\end{array}$ & 0 & 0 & 0 & 0 & 0 & 0 & 0 & 0 & 0 \\
\hline $\begin{array}{l}\text { Whether Health checks } \\
\text { up are regularly done } \\
\text { on site? }\end{array}$ & 0 & 1 & 1 & 1 & 1 & 1 & 1 & 1 & 87.5 \\
\hline $\begin{array}{l}\text { Whether reports on } \\
\text { health of labour are } \\
\text { maintained? }\end{array}$ & 0 & 1 & 1 & 1 & 1 & 1 & 1 & 1 & 87.5 \\
\hline $\begin{array}{l}\text { Whether training } \\
\text { programme held on the }\end{array}$ & 0 & 1 & 1 & 0 & 1 & 0 & 0 & 0 & 37.5 \\
\hline
\end{tabular}




\begin{tabular}{|c|c|c|c|c|c|c|c|c|c|}
\hline site? & & & & & & & & & \\
\hline $\begin{array}{l}\text { Whether rest room and } \\
\text { recreational room are } \\
\text { present at the site? }\end{array}$ & 0 & 0 & 0 & 0 & 0 & 0 & 0 & 0 & 0 \\
\hline $\begin{array}{l}\text { Whether report on } \\
\text { workmen habitant is } \\
\text { maintained at the site? }\end{array}$ & 0 & 0 & 0 & 0 & 0 & 0 & 0 & 0 & 0 \\
\hline $\begin{array}{l}\text { Whether reports on } \\
\text { environmental impact } \\
\text { due to construction } \\
\text { practise are maintained } \\
\text { at site? }\end{array}$ & 0 & 0 & 0 & 0 & 0 & 0 & 0 & 0 & 0 \\
\hline OUTPUT & & & & & & & & & \\
\hline $\begin{array}{l}\text { Is team work among } \\
\text { labours present at the } \\
\text { site? }\end{array}$ & 1 & 1 & 1 & 1 & 1 & 1 & 1 & 1 & 100 \\
\hline $\begin{array}{l}\text { Whether motivations in } \\
\text { the form of incentives } \\
\text { are given to the labours } \\
\text { at site? }\end{array}$ & 0 & 0 & 0 & 0 & 0 & 0 & 0 & 0 & 0 \\
\hline $\begin{array}{l}\text { ¥Whether late delivery } \\
\text { of material (R.M.C, } \\
\text { steel) occurs on site? }\end{array}$ & 1 & 0 & 0 & 1 & 0 & 1 & 1 & 1 & 62.5 \\
\hline $\begin{array}{l}\text { Whether shortage of } \\
\text { material occurs at the } \\
\text { site? }\end{array}$ & 1 & 0 & 0 & 1 & 0 & 1 & 1 & 0 & 50 \\
\hline $\begin{array}{l}\text { Whether BMC approval } \\
\text { [CC] work problems } \\
\text { are faced on site? }\end{array}$ & 1 & 0 & 0 & 1 & 0 & 1 & 1 & 1 & 62.5 \\
\hline $\begin{array}{l}\text { Whether wages for } \\
\text { overtime are present at } \\
\text { the site? }\end{array}$ & 1 & 1 & 1 & 1 & 1 & 1 & 1 & 1 & 100 \\
\hline $\begin{array}{l}\text { Whether } \\
\text { communication } \\
\text { problem are faced on } \\
\text { the site? }\end{array}$ & 0 & 0 & 0 & 0 & 0 & 0 & 0 & 0 & 0 \\
\hline $\begin{array}{l}\text { \#Whether lack of } \\
\text { manpower skill and } \\
\text { experience in labour are } \\
\text { seen at site? }\end{array}$ & 0.5 & 0 & 0 & 0.5 & 0 & 0 & 1 & 0 & 37.5 \\
\hline SAFETY & & & & & & & & & \\
\hline $\begin{array}{l}\text { Whether exclusive } \\
\text { safety engineer is } \\
\text { appointed on site? }\end{array}$ & 0 & 1 & 1 & 0 & 1 & 0 & 0 & 0 & 37.5 \\
\hline $\begin{array}{l}\text { Whether safety norms } \\
\text { are strictly followed at } \\
\text { site? }\end{array}$ & 0 & 1 & 1 & 0 & 1 & 0 & 0 & 0 & 37.5 \\
\hline $\begin{array}{l}\text { Whether Personal } \\
\text { Protective Equipment } \\
\text { (P.P.E) is provided to } \\
\text { the labours and an } \\
\text { when required on site? }\end{array}$ & 1 & 1 & 1 & 1 & 1 & 1 & 1 & 1 & 100 \\
\hline
\end{tabular}

REMARKS: $0=$ Between $0 \%$ to $25 \%$
$0.5=$ between $25 \%$ to $75 \%$

$\# 1=$ Between $75 \%$ to $100 \%$

$¥=$ for R.M.C late delivery is considered $30 \mathrm{~min}$ after the expected delivery time and for steel late Delivery is considered 2 days after the expected delivery time

\section{OVERVIEW BASED ON COMPARISON} BETWEEN ACTUAL OBSERVATIONS AND NATIONAL BUILDING CODE (N.B.C) RECOMMENDATIONS

* WELFARE

\section{1) DRINKING WATER FACILITY}

Out of the site, which are visited only $37.5 \%$ of sites are having wholesome and sufficient water. It is observed that water is provided by BMC and the same water is being used for drinking purpose, washing purpose etc. In case, of shortage of water, tanker provided water is called to meet the demand of water at site. Sometimes, bore wells are constructed on sites but the water through bore wells and tanker provided water which are used for drinking purpose are not checked and tested by accredited laboratories for the quality specifications. National Building Code (NBC) states, "Drinking water sampling and testing for checking its conformity to requirement such as sufficient quantity of portable water should be carried out quarterly through accredited laboratories".

\section{2) W/C UNITS}

It is observe, that at every site adequate numbers of sanitary units are present.All the visited sites followed the NBC's requirement, which is related to sanitary units i.e. the National Building Code (NBC) recommends minimum one lavatory per ten people is the minimum requirement.

\section{3) SANITARY SERVICES}

$37.5 \%$ of the sites are found to have good services of sanitary units likes water facilities, lighting and hygienic condition and remaining $62.5 \%$ of the sites which are visited are not having proper hygienic condition. Sanitary units are not hygienic and water is not provided through taps in the sanitary units. The latrines do not have proper doors and fastenings. It is also found that the walls, ceilings and partitioned walls are not maintained inacceptable conditions i.e. not colour-washed since long time. Whereas National Building Code (NBC) states that provision of water shall be done by installation of taps or it shall be easily available in or to the vicinity of each units of latrines or urinals. It also states that each latrine shall be well covered and well partitioned so as to achieve degree of privacy and shall have well maintained doors and fastening. The walls, partition walls and ceilings shall be painted with whitewashed or colour-washed at an regular interval of 4 months. 


\section{4) SEPARATE TOILETS FOR MALE AND FEMALE}

Now a days on construction site no female worker are employed so usually separate sanitary units are not available on the sites. In very rare cases it has been observed that women are employed. For such situation NBC recommend that separate sanitary services shall be made available at the site for female workers. Outside each unit of latrine or urinals a note displaying "MALE TOILET" or "FEMALE TOILET" or may be written in any language which can be understand by maximum of workers and this note should be accompanied by the figure of man and woman respectively.

\section{5) CANTEEN ON NO EARNING BASIS}

Out of the total sites, which are visited, only $25 \%$ of the sites are having canteen on no earning basis. From above observation, it is concluded that canteen provisions is mainly dependent on the extent of work on the site .But National Building Code (NBC) states, "Each and every site should at least have one canteen on no earning basis irrespective of extent of site".

\section{6) HEALTH CHECK-UP HEALTH REPORT}

Out of the total sites, $87.5 \%$ of the sites are found to have health check-up at an interval of 1 month by the doctors having qualification of BAMS, MBBS etc. and on the same sites health report are maintained. Health data sheets are prepared which includes the health report of labours. Inspection by local health authorities are carried out once in six month. NBC states that reports regarding managing occupational physical hazards and provision of personal protective equipment required for report should also include the various hygiene control methods while laying down construction. Also regarding health check-up N.B.C states, "check-up once in 6 months shall be carried out by a registered medical practitioner".

\section{7) FIRST AID CENTRE}

It is observe, that none of the site are having first aid centre facilities available. Only first aid boxes are maintained at the site which are regularly check by the doctors when they visit site for health check- up. NBC recommends that "There should be trained first aiders/male nurse/doctors in the first aid centre depending upon number of labours and emergency vehicle shall be made available during emergency".

\section{8) TRAINING PROGRAMME REGARDING}

\section{SAFETY AND ACHIEVING TASK WORK}

Out of all the sites, $37.5 \%$ are observe to have training sessions conducted for the labours regarding achievement of task work and safety and at remaining sites, no training programmes are held for the labours. It is also observe that the method of training programmes depends on the extent of site. For example for multi-storey building, construction up to 7 floor, only monthly training session are conducted by experienced foreman but in megaprojects and high rises ,10 minutes daily training session are held by project manager and safety engineer.NBC states that formal training or certified course under taken shall be considered the selection criteria for the workers .Labour (skilled or unskilled) shall be given training regarding safety education, developing technical knowledge, quality and general awareness. Security staff appointed on the site shall be trained adequately regarding first aid, fire fighting and emergency attentiveness and emergency lights, torches and other accessories necessary during emergency shall provide them. Crane driver and hoisting equipment operator must undergo necessary through a formal training at any institute of national importance and temporary work coordinator must possess adequate field training for temporary works.

\section{9) RECREATION AND REST ROOM FACILITY}

It is observe, that at none of the sites recreational facilities is made available for the labour whereas NBC states that internal as well as external recreational facilities may be made available depending on the number of workers to be accommodated at the site. Internal recreation facilities include a room with indoor games like carom board, television etc. should be made available for labours. External recreation facilities include a kabbadi court or an area for screening movies within habitat.

\section{0) WORKMEN HABITAT REPORT}

It is observe, that none of the sites which maintained report on Workmen habitat i.e. regarding access, living area, kitchen, utility area etc. Whereas NBC states that workmen habitat report should be maintained in order to implement the suggested measures. Inspection shall be carried out periodically. Inspection of habitat shall be carried out by an identified team once in a month regarding access for example living area, Kitchen, utility area and general such as disinfection activities carried out on weekly basis such as garbage being disposed of on regular basis.

\section{1) ENVIRONMENTAL REPORT}

It is observe, that none of the sites studied, maintained report on impact on environment due to construction practices.NBC states that it is essential to minimise the adverse environmental impact of activities and limiting any adverse impact within the laws or prescribed norms. Management of disposal of waste and considering positive environmental contribution particularly after completion of construction .NBC also states that safety of environment while working with hazardous materials and maintaining safety data sheets is very important

\section{* OUTPUT}

\section{1) TEAMWORK}

On all the sites, which are studied it is found that teamwork among labour gangs is present. It is fact that effective teamwork in construction project is very essential to achieve the goal of the project. Effective teamwork may be achieved 
when each member of the team in construction project having duties and responsibilities will function effectively. Project manager has the ultimate responsibility and authority to run the project on day-to-day basis. Proper initial planning, designing, analysing, monitoring and controlling the activities until the closure of project are key principle for achieving proper team work.

\section{2) MOTIVATION IN TERMS OF INCENTIVES}

It is observe, that at all the sites, motivations in term of incentives are not given to the labours .Motivations encourages the labours and increases their productivity. Motivation helps the construction workers to recognize their talent, hard work and harness their skills, which will eventually benefit the company. Motivation to the labours can be given by creating an employee reward system for show casting the talent of construction worker. By announcing opportunities for advancement and giving current workers chance to apply for supervisory. Enabling decision making among work force motivates construction workers as it empowers them and helps them feel their input on their work.

\section{3) LATE DELIVERY OF MATERIAL}

It is observe, that $62.5 \%$ of the site, which are studied had an issue of late delivery of material at the site. Due to the late delivery of material, the progress of the project is delayed. Delaying of the project will cause in loss of the revenue and higher material cost through inflation. Proper management plans, effective communication and coordination with other parties are crucial factors that will minimize the adverse effect caused by late delivery of material at the site.

\section{4) SHORTAGE OF MATERIAL AT SITE}

At $50 \%$ of the sites, which are studied, regularly shortage of materials occurred at the sites. Shortage of materials can be overcomes by inventory accuracy, by reducing excess stock buffering, and eliminating the stocks checks during down time. Shortage of material causes stopping of work, so labour remains vacant and client may suffer production losses. This may even results into time and cost overruns.

\section{5) B.M.C APPROVAL PROBLEMS}

At $62.5 \%$ of the sites, which are studied, clearances from $\mathrm{BMC}$ are almost the major hindrance that is face at the site. The sites get stopped for 6 month or even more for getting completion certificate from BMC due to which labour suffer unemployment.

\section{6) WAGES FOR OVERTIME}

All the sites that are studied provided wages for over time to labour according to the guidelines provided by Minimum wages act, 1948. Minimum wages act, 1948 for year 2013 states that when a labour, having minimum amount of wages is secured under this Act on day or working hour basis and if he works on any day for extra number of hours as compared to normal working day than the worker shall be waged for each hour at the overtime rate fixed under this Act. It also mentions that overtime wages should be rewarded at the rate of twice the standard rates of wages of the workers.

\section{7) COMMUNICATION PROBLEMS}

At every site, which are studied, no communication problems are faced by the labours. In India, communication problem does not affect the productivity of construction worker.

\section{8) MANPOWER SKILLED AND EXPERIENCE}

At $85 \%$ of the site, which are studied, it is observe, that adequate amount of skilled and experience workers are available. It is observe that under every skill labour, four semiskilled labours are working. Initially unskilled labour works as a helper at the site and later on as the time passes with the ability of his talent and skills he is upgraded as semi-skilled and then to skilled labour. Shortage of skill workers hinders the progress of work tending in the delay of project. If semi-skilled workers and poor supervisors are hired, it will result in $20-30 \%$ of wastage and redoing of the work as well as delay in completion time of the projects. This would naturally have a great impact on productivity of the site. Considering the fact that the construction sector is the second largest economic activity after agriculture, a separate ministry exclusively for construction industry would be highly recommended. There is a need for the government to have more flexible legislation as well as incentives to ensure that skilled manpower is deployed. Certified courses should be run across the nation to ensure the supply of skilled manpower.

\section{* SAFETY}

\section{1) EXCLUSIVE SAFETY ENGINEER ARE} APPOINTED

It is observe, that only $37.5 \%$ of the sites, which are studied, have exclusive safety engineer and in the remaining sites, there are no safety engineers appointed. At these sites where no safety engineer is appointed, the safety of the labours are under the responsibility of the site engineers and decision to appoint a safety engineer depends upon the overall cost of project and the extent of work. However, NBC states that every site must compulsory appoint a safety engineer irrespective of the cost of project and extent of the site

\section{2) SAFETY NORMS}

Only at $37.5 \%$ of the site where safety engineer are appointed, the safety norms are strictly followed as per NBC recommendation. At $62.5 \%$ of the sites where safety engineer is not appointed, it is observed that personal safety is followed by labours at their individual level .Safety engineer should be compulsorily present on all the sites so that the safety norms are strictly followed and accidents and deaths are avoided. 


\section{3) P.P.E ARE PROVIDED TO THE LABOURS AS AND WHEN REQUIRED}

All the sites, which are studied, PPE like safety shoes, helmets etc. are provided once in a year to the labours but if any accident happens resulting in wear and tear of PPE, then again PPE is replaced by company and provided to the labour free of cost. Also if PPE is misplaced by the labours themselves due to their carelessness, then personally labour has to buy PPE on his own expenses.NBC states that provision of PPE required for specific health hazard must be given to the labours. All necessary PPE like full body harnesses, safety helmets and safety shoes as considered suitable should be made available for the use of employers on the site and it should be sustained in good condition appropriate for instant use. When creosoted wood piles are being driven ,PPE and barrier creams must be provided to avoid eye and skin injuries from splashes of creosote.

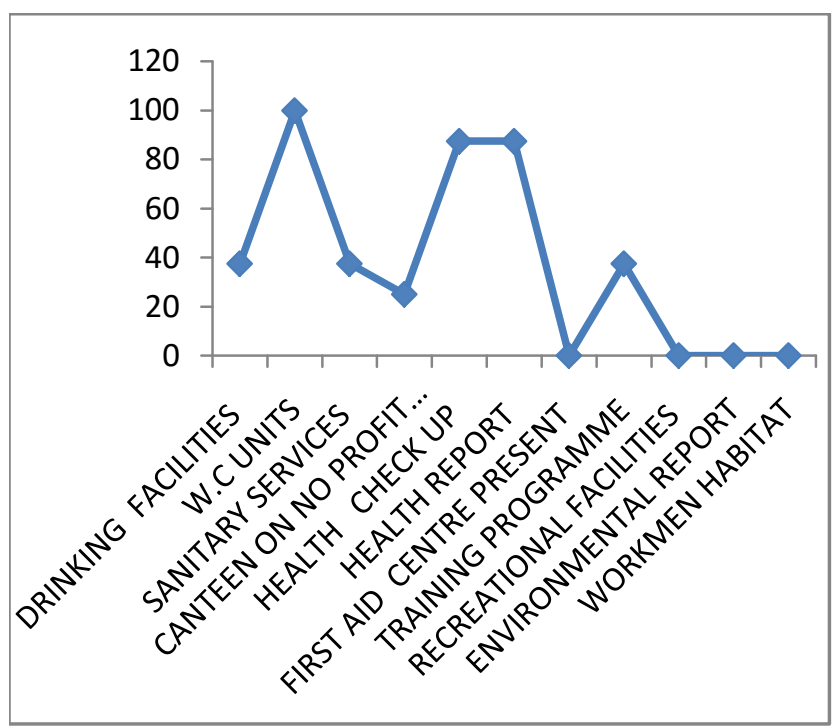

Chart -1: Welfare

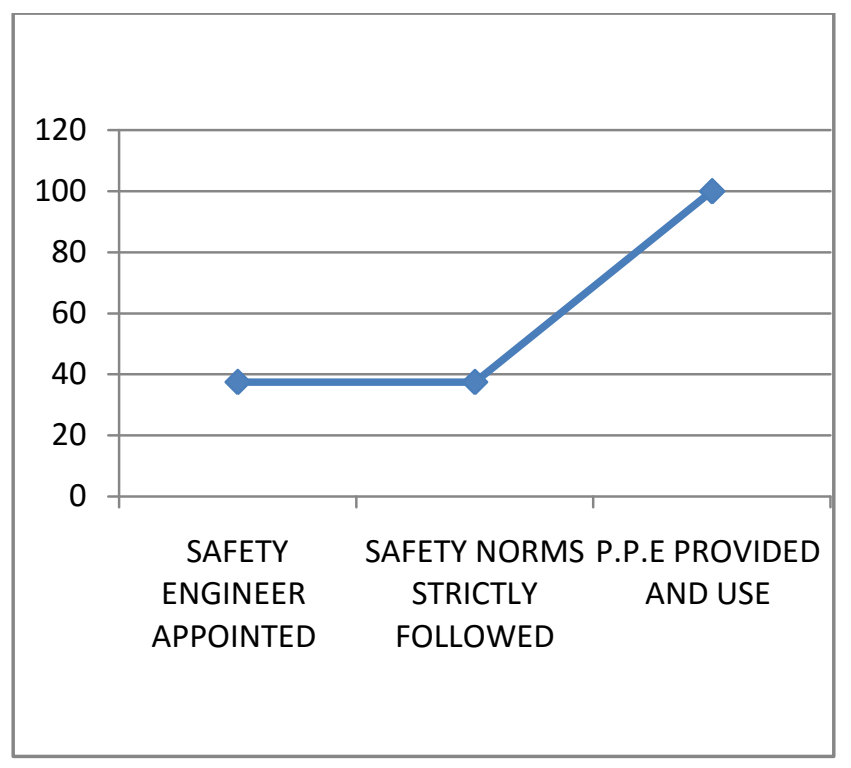

Chart-2: Safety

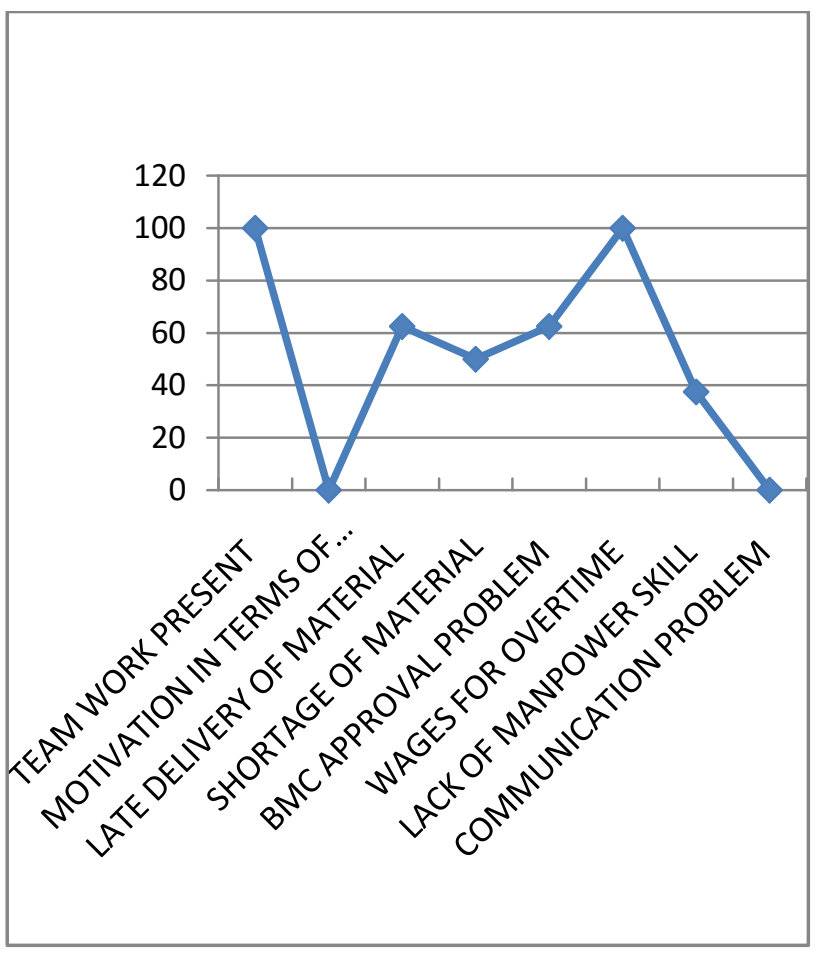

Chart-3: Output

\section{CONCLUSION}

The overview study of labour's output, welfare and safety, is conclusive that there is a huge gap between the guidelines given in the NBC for the safety, welfare and output of labours and the actual practices followed on the site. It is observed that the guidelines given in the NBC becomes nonrealistic on building construction sites .In fact the basic needs of labour are not available at the sites. Therefore, it is recommended that NBC should provide realistic guidelines that may meet the basic requirement and should be easily adopted at the sites. The major setbacks in NBC are that the guidelines prescribed are same for all large extent as well as small extent sites. These guidelines are willingly followed by large extent sites due to their high project budget but it is resisted by small extent sites with low budget. Therefore, it is highly recommended that NBC should prescribe specific levels of guidelines depending upon the overall project cost and the total construction area in sq. ft. or sq. Mt. It has been seen that the sites with huge extent of work for example in the present study, site 2 and site 3 which are mega project of high rise buildings, shows more concern for labour safety and welfare as these sites invest a huge amount of capital to get the required productivity. NBC should provide the guidelines for appointing the inspection team for checking the safety and welfare condition at the site periodically with respect to the work extent of the site. Construction industry is the second largest source of employment so a separate legislation should be proposed for construction labour related to construction workers. The other factors like shortage of materials can be achieved through proper material management. The detail schedule of material supply, proper vendor analysis and vendor selection and bill of quantity should be prepared. Shortage of materials can be avoided by ordering in advance considering proper time lag 
between order placement and delivery of materials. Modern tools, plants and equipment should be provided with appropriate safety measures to make easy and speedy transportation of materials. Revisions of drawing should be avoided as much as possible and additional works should be informed earlier to avoid delay of work. Absenteeism at work site can be reduced with inclusion of appropriate paid time off and vacations to all employees. Motivation to the labors in terms of incentives should be awarded to the labours to create encouragement and competition among them.Safety can be achieved through conducting periodic safety induction programs.Inspections for drug and alcohol tests should be implemented on sites on surprise basis and strict action should be taken with the employees whose tests are positive to achieve safety and discipline at working sites. A national or state level certified training programs must be run and made compulsory for the labours at the cost of the labour contractor/clients so as to improve their skill and talent.

\section{ACKNOWLEGEDMENT}

The authors want to thank Prof. Shagufta Sajid Mumtaaz Sayed for her guidance and supervision. The authors express special gratitude to all the personnel who had given their precious time, attention and information about their sites.

\section{REFERENCE}

[1].Yates, J. K., and S. Guhathakurta. "International labour productivity" COST ENGINEERING-ANN ARBOR THEN MORGANTOWN- 35 (1993): 15-15.

[2].McTague, Bob, and George Jergeas. Productivity Improvements on Alberta Major Construction Projects: Phase I-Back to Basics. Alberta economic development 2002.

[3].ILO (2001) The Construction Industry in the TwentyFirst Century: Its Image, Employment Prospects and Skill Requirements, International Labour Office, Geneva.

[4]. Henry MwanakiAlinaitwe (April 2006 ) "Labour Productivity in the Building Industry - Studies of Uganda "Licentiate Thesis, ISSN 1651 - 0380, Construction Management Publications ISBN 91-85257-05-2 Construction Management 06/1020-SE.

[5]. Alienate, Henry Mwanaki, Jackson A. Mwakali, and Bengt Hansson. "Factors affecting the productivity of building craftsmen-studies of Uganda. "Journal of Civil Engineering and Management 13.3 (2007): 169-176.

[6]. Homyun Jang, Kyonghoom Kim, Juhyung Kim, and Jaejun Kim. (2011). Labour productivity model for reinforced concrete construction projects. Construction Innovationm Process, Manag

[7].Durdyev, S., \&Mbachu, J. (2011). On-site Labour Productivity of New Zealand Construction Industry: Key Constraints and Improvement Measures. Australasian Journal of Construction Economic ement, 11(1), 92-113. and Building, 1(3), 18-33.

[8].Enshassi, A., Mohamed, A., Mustafa, Z. A., \& Mayer, P. E. (2007). Factors affecting labour productivity in building project in the Gaza strip. Journal of Civil Engineering and Management, 8(4), 245-254.
[9].Soekiman, A., Pribadi, A. S., Soemardi, B. W., \&Wirahaddikusumah, R. D. (2011). Factors relating to labour productivity affecting the project schedule performance in Indonesia. Procedia Engineering, 14(10), 865-873.

[10]. National Building Code Of India (Part 7 Construction Management, Practices And Safety [THIRD REVISION OF SP (PART 7)]) DOC: CED 46 (8018)WC August 2015 available at URL http://www.bis.org.in/sf/wcdraft.asp

\section{BIOGRAPHIES}

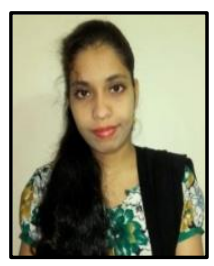

\begin{abstract}
AJBA SHABBIR AHMED PAWLE have completed diploma from SHREERAM POLYTECHNIC, AIROLI college and now pursuing Bachelor's degree in CIVIL ENGINEERING from SABOO SIDDIK college of engineering . being CIVIL ENGINEER my aim is to
\end{abstract} achieve the CIVIL ENGINEERING aspects ajbapawle4@gmail.com

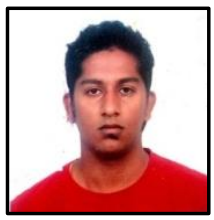

MOHIT SURYAKANT JADHAV CHAPRA have completed my H.S.C from BHAVAN HAZARIMAL SOMANI college and now pursuing Bachelor's degree in CIVIL ENGINEERING from SABOO SIDDIK college of engineering . Being CIVIL ENGINEER my aim is to achieve the CIVIL ENGINEERING aspects mohitjad2594@gmail.com

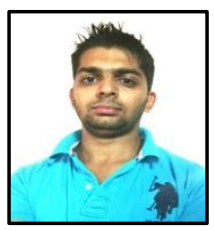

MOHD AHMED CHAPRA have completed my H.S.C from S.T MARY'S JR college and now pursuing Bachelor's degree in CIVIL ENGINEERING from SABOO SIDDIK college of engineering . being CIVIL ENGINEER my aim is to achieve the CIVIL ENGINEERING aspects ahmedchapra8@gmail.com 